\title{
CAMBRIDGE
}

\section{Transformational Grammar}

A Student's Guide to Chomsky's Extended Standard Theory

Andrew Radford

An easy-to-follow introduction to current work in syntax by Noam Chomsky and his followers. Among the subjects covered are X-Bar Syntax, Conditions on Transformations, Deletion, Filters, Case Theory, and Binding. Valuable exercises reinforce the text.

Cambridge Textbooks in Linguistics Hardcover $\$ 39.50$ Paper $\$ 12.95$

\section{Syntax}

\section{P.H. Matthews}

This wide-ranging presentation of the basic concepts of Syntax is designed to fill the gap between the teaching of English grammar and the teaching of modern theoretical models. Unlike most books on syntax, it is not tied to the theoretical model of any particular school. Cambridge Textbooks in Linguistics Hardcover \$36.50 Paper \$11.95

\section{Georgian Syntax}

A Study in Relational Grammar

\section{Alice C. Harris}

Working in the framework of relational grammar, Harris shows that Georgian does have constructions found in better-known languages. This study is one of the best available in English of non-Indo-European syntax.

\section{Explanations in the Study of Child Language Development}

\section{Martin Atkinson}

This book proposes a number of conditions that theories of language acquisition should fulfill in order to be properly considered explanations. It grows out of Atkinson's dissatisfaction with the current state of theorizing. Hardcover \$39.95 Paper \$12.95

\section{Teaching and Learning Languages \\ Earl Stevick}

Drawing on his thirty-two years of experience, Stevick explains what makes the difference between success and failure in the teaching and learning of languages.

Hardcover \$15.95 Paper \$6.95 


\section{Accents of English}

Volume 1: An Introduction

Volume 2: The British Isles

Volume 3: Beyond the British Isles

John C. Wells

The first comprehensive study of how English is pronounced by different people in different places. The author provides an integrated framework for existing scholarly treatments of regional forms of speech. He also makes many original contributions, including the description of accents where there is currently no field research available as well as the identification and naming of a number of phonological processes, both historical and synchronic.

$\begin{array}{lll}\text { Volume 1 } & \text { Hardcover } \$ 34.50 & \text { Paper \$10.95 } \\ \text { Volume 2 } & \text { Hardcover \$29.50 } & \text { Paper \$ } 9.95 \\ \text { Volume } 3 & \text { Hardcover \$29.50 } & \text { Paper \$ } 9.95\end{array}$

\section{Semantics}

Second Edition

\section{F.R. Palmer}

Review of the first edition:

"...the most enlightening book on semantics I've yet to read. He treats the important issues with grace and skill..."-The Modern Language lournal

Hardcover $\$ 29.50$ Paper $\$ 8.95$

\section{Socio-Historical Linguistics}

Its Status and Methodology

\section{Suzanne Romaine}

Romaine lays the foundations for a new field of research that attempts to explain language variation in a given speech community over time.

\section{Mind and Meaning}

\section{Brian Loar}

Loar offers a theory to answer the questions: Is linguistic meaning independent of the states of mind of language users, or can it be explained only in terms of them? If the latter, what account of the mental states in question avoids circularity? Cambridge Studies in Philosophy $\$ 34.95$

\section{A Functional Approach to Child Language}

A Study of Determiners and Reference

Annette Karmiloff-Smith

Now in paperback $\$ 12.95$

all prices subiect to change 


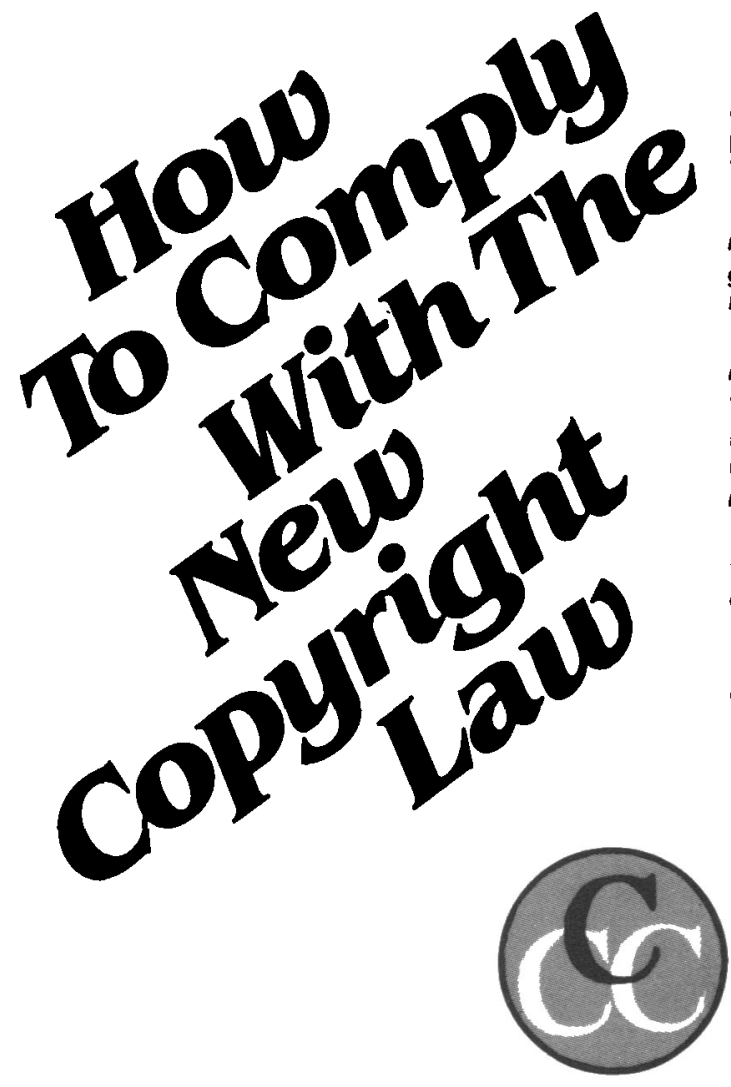

Participation in the Copyright Clearance Center (CCC) assures you of legal photocopying at the moment of need. You can:

Fill requests for multiple copies, interlibrary loan (beyond the CONTU guidelines), and reserve desk without fear of copyright infringement.

Supply copies simply and easily from registered publications. The CCC's flexible reporting system accepts photocopying reports and returns an itemized invoice. You need not keep any records, our computer will do it for you.

The Copyright Clearance Center is your one-stop place for on-the-spot clearance to photocopy for internal use. You will never have to decline a photocopy request or wonder about compliance with the law for any publication registered with the CCC.

For more information, just contact:

\section{Copyright}

\section{Clearance Center}

21 Congress Street

Salem, Massachusetts 01970

(617) $744-3350$

a not-for-profit corporation 


\section{NOTES FOR CONTRIBUTORS}

Contributions are welcomed from all countries. They should be written in English. All articles, as well as books for review and listing, should be sent to the Editor, Professor Dell Hymes, Graduate School of Education, University of Pennsylvania, Philadelphia, Pennsylvania I9I04, USA.

Typescripts. The original typescript plus one copy should be submitted. Authors should hold a copy for correction of proofs. Contributions should be clearly typed, double-spaced, on $8 \frac{1}{2} \times$ I I $^{\prime \prime}$ or A4 paper. Figures should be ready for photographic reproduction; any labels and details should be clear and large enough to remain legible after a reduction to halfsize. The article title-page should include the title, author's name and affiliation (in that order), along with an abstract of the article. Areas of study to which the articles may be of interest should be listed at the end of the abstract.

Titles should be so worded that the first part may be used as a running headline (with a maximum length of 50 characters, including spaces). They should be typed on a separate sheet, together with the author's name and address to which proofs are to be sent.

Citations and forms of emphasis. Normally the Latin alphabet is to be used. Cited forms should be underlined to represent italicization in print. Translation "meanings" should be placed within single quotation marks.

References are to be made in the text (and not in footnotes) by giving in parentheses the name of the author and year of publication, and where relevant the page(s) referred to; e.g., (Whitney 1867: 45-53). If the author's name is part of the text, the following form should be used: "Whitney (1867: 48) maintained that..."'. When a work written by two or more authors is referred to, all names should be given in the first citation; e.g., (Weinreich, Labov \& Herzog 1968). In subsequent citations the first name only should be given, with "et al." added; e.g., (Weinreich et al. 1968). When separate works are referred to in the same parentheses, those by the same author should be separated by commas and those by different authors by semi-colons: e.g., (Whitney 1867; Firth 1935, 1957a). Initials should be used (after the author's name) only when it is necessary to distinguish between two or more authors of the same name, all of whom are referred to in the same article.

All works referred to should be listed at the end of the article, double-spaced and in alphabetical order.
Examples of references (note the use of punctuation marks within references):

Firth, J. R. (1957a). Ethnographic analysis and language with reference to Malinowski's views. In R. W. Firth (ed.), Man and culture: An evaluation of the work of Bronislaw Malinowski. London: Routledge and Kegan Paul. 93-I I8.

(1957b). A synopsis of linguistic theory, 1930-55. Studies in linguistic analysis (Special volume of the Philological Society). Oxford. I-33.

Sapir, E. (r929). The status of linguistics as a science. Language 5, 207-14. (Reprinted in D. G. Mandelbaum (ed.). (1939) Selected writings of Edward Sapir. Berkeley and Los Angeles: University of California Press I60-66.)

Book reviews. With the exception of the title-page, book reviews should be submitted in the same form as articles. The title-page should take the following form: Edwin Ardener (ed.), Linguistic and social anthropology. (ASA Monographs, I0.) London: Tavistock, 197I. On the last page, following the entire review text (including footnotes and references) the review author's name and address should be given as follows:

\section{Reviewed by Suzanne Romaine Department of Linguistics University of Birmingham Birmingham B15 2TT, England}

There is no need to submit an abstract with a book review.

Proofs. First proofs only will be sent to the author (or a nominee), who will be expected to correct them and return them to the Editor, by airmail where appropriate, within three days of receipt.

Offprints. 25 offprints of both articles and review articles will be provided free of charge. Additional offprints may be purchased if ordered at proof stage

Submission of an article is taken to imply that it has not previously been published, or is not being considered for publication elsewhere. If an author is publishing a related article elsewhere, this fact should be stated.

Copyright. Contributors of accepted articles will be asked to assign their copyrights, on certain conditions, to Cambridge University Press, to help protect their material, particularly in the U.S.A. 


\section{Language in Society}

Volume II Number I April 1982

ARTICLES

J. A. Fishman: Whorfianism of the third kind: Ethnolinguistic diversity as a worldwide societal asset

A. D. Grimshaw: Comprehensive discourse analysis: An instance of professional peer interaction

S. B. HEATH: What no bedtime story means: Narrative skills at home and school

E. OcHs: Talking to children in Western Samoa

REVIEWS

Dimensions of sociolinguistics

G. SANkofF: The social life of language (Stoller)

D. Bolinger: Language - the loaded weapon: The use and abuse of language today (Fairclough)

P. C. Rollins: Benjamin Lee Whorf: Lost generation theories of mind, language, and religion (Alford)

\section{Language situations}

M. Clyne (ed.): Australia talks: Essays on the sociology of Australian immigrant and aboriginal languages (Rigsby)

R. M. W. Dixon: The languages of Australia (Feld)

D. C. Gordon: The French language and national identity (Sankoff)

C. FEAGIN: Variation and change in Alabama English: A sociolinguistic study of the white community (Davis)

E. C. Polomé \& C. P. Hill (eds.): Language in Tanzania (Gilman)

Language varieties and genres

M. R. WALROD: Discourse grammar in Ga' dang (Frank)

J. C. SAger, D. Dungworth, \& P. F. McDonald: English special languages: Principles and practice in science and technology (Andrews)

J. H. McDowelL: Children's riddling (Sutton-Smith)

Brief notices

Publications received

(C) Cambridge University Press 1982

CAMBRIDGE UNIVERSITY PRESS

The Pitt Building, Trumpington Street, Cambridge $\mathrm{CB}_{2}$ I RP, England 32 East 57 th Street, New York, NY 10022, USA 296 Beaconsfield Parade, Middle Park, Melbourne 3206, Australia

Printed in the United States of America 